\title{
SPECIFICITY OF THE ACTION OF SILENCE IN JAPANESE COMMUNICATION CULTURE
}

\section{Nadira Tashmirzaevna Khalmurzaeva}

Doctor Of Philology Of Philosophy, Associate Professor Tashkent State University Of Oriental Studies Tashkent, Uzbekistan Qudratulla Sharipovich Omonov

Doctor Of Philology, Professor Tashkent State University Of Oriental Studies Tashkent, Uzbekistan Gulchekhra Shavkatovna Rikhsieva

Doctor Of Philology Of Philosophy, Associate Professor Tashkent State University Of Oriental Studies Tashkent, Uzbekistan Khulkar Vasilovna Mirzakhmedova

Doctor Of Philology Of Philosophy, Associate Professor Tashkent State University Of Oriental Studies Tashkent, Uzbekistan

\section{ABSTRACT}

The Japanese are always wary of what they say, fearing of hurting the feelings of others, and often even use silent gestures to get along with their interlocutors.

Therefore, in Japanese discourse, communication is determined not only by words, but also by the actions of silence.

This article describes the peculiarities of the operation of silence in the Japanese language culture. In this regard, first of all, the features, role and tasks of silence in Japanese discourse are considered. It is also supposed to consider silence as an action and take into account the ambiguity of its interpretation. On the other hand, studying the classification of the action of silence helps to understand the behavior of silence that occurs in discourse.

The article examines the culture of silence in terms of dynamic and spiritual interaction and finds that the interpretation of the action of silence can be understood on several levels, given the perspective of interaction between speaker and listener. That is, it is assumed that the meaning of the action of silence can be classified as an action that allows for multilevel interpretation.

KEYWORDS: - Silence, Japanese culture, communication, discourse, context, action, speech act.

\section{INTRODUCTION}

In Japanese, 沈黑timmokumeans silence, not as a pause between words in a stream of speech acts, but as a specific communication movement. [1, p. 51].

Silence can be misunderstood even by the Japanese themselves, not to mention the foreigners who communicate with them. For example, between Europeans and Americans, the pause that occurs during communication usually causes some discomfort and often nervousness.

Mechkovskaya [2], “In Western cultures, communication should not be interrupted, it should be supplemented with speech; at the very least, it is customary to create a view of the exchange of 
CURRENT RESEARCH JOURNAL OF PHILOLOGICAL SCIENCES 2(8): 50-55,

May 2021 DOI: https://doi.org/10.37547/philological-crjps-02-08-12

ISSN 2767-3758

(C)2021 Master Journals

Crossref doi) 81 Google

Accepted26 ${ }^{\text {th }}$ August, 2021 \& Published $31^{\text {th }}$ August, 2021

information. In Japan, meanwhile, silence is tantamount to disconnection and nothing to blame. On the contrary, it is a necessary component of communication. "Many people in other countries thought that the fact that the Japanese way of communicating was characterized not only by silence, but also by avoidance of speech, could be considered a "waste of time."

It is this understanding that often leads to misunderstandings between Japanese and Western carriers.

According to T. M. Gurevich, " the Japanese are called the bearers of the traditional culture of silence as the polite representatives of the culture of communication" [3, p. 299].

Silence is usually an action that is different from speech or sound and represents a state of lack of communication or pause [4, p. 9].

By silence, it plays a different role in both communication and speech, so it is an action like speech. The boundary between silence and speech is not very clear [5, p. 17].

Expressing intentions and feelings by silence is a very indirect expression, and expressing silence as an action can be recognized in national culture.

\section{RESEARCH MATERIALS AND ANALYSIS}

The main purpose of our study is to describe the peculiarities of the silence action in Japanese language culture. In this regard, it is important, first of all, to define the features, role and functions of silence in Japanese communication. It is also intended to consider silence as an action and to consider the ambiguity of its interpretation. The study of silence classification helps to understand the silence behavior that occurs in discourse.
By silence, the reprinting of different interpretations is interpreted in terms of vague action [6]. The ambiguity in the interpretation of silence lies not only in the question of meaning expressed by silence, but also in the question of whether silence is a form of discourse. To us, the question of who will help the participants of the discourse by silence is also on the head.

The Japanese value the sensitivity of the interlocutor, depending on the situation on their part, but also to consider other points of view. The Japanese believe that the silence in communication is related to a clear knowledge of the social hierarchy in their group and in society as a whole. It is considered obscene to speak openly against someone in a high position.

The Japanese may interpret silence differently depending on the situation. There are several silence functions. The Japanese use silence not only to prevent conflicts, but also, for example, to upset the interlocutor or to prolong communication with him. By silence, they show a negative attitude towards the other person by ignoring them. You can also defend your point of view by silence or pay attention to what is being said. Silence can be a way to avoid direct remarks that may offend the other person. So, we can say that silence can be positive or negative.

Before understanding how to work "honne and tatemae" , it is important to study the interactions of certain features of Japanese culture, such as rejecting open statements, which means "high-context culture" and "low-context culture". [7, p.19-30]. The main characteristics of high-context cultures include: unexpressed, covert speech style, meaningful and numerous pauses; the serious role of non-verbal communication and the ability to "speak with the eyes" ; data overload because initial data is sufficient for communication; there is no clear expression of protest in any circumstances and as a result of communication. The main features of low-context cultures are: direct and expressive style of speech; an 
CURRENT RESEARCH JOURNAL OF PHILOLOGICAL SCIENCES 2(8): 50-55,

May 2021 DOI: https://doi.org/10.37547/philological-crjps-02-08-12

ISSN 2767-3758

(C)2021 Master Journals

Crossref doi) 81 Google

Accepted $26^{\text {th }}$ August, 2021 \& Published $31^{\text {th }}$ August, 2021

insignificant proportion of non-verbal forms of communication; make a clear assessment of all topics and issues discussed; assess underestimation as insufficient incompetence or poor awareness of the interviewee; a clear expression of protest, a bridge of harmony and respect for tradition. Fearing to hurt the feelings of others, the Japanese are always wary of their own words and often use the tatema to get along well with their interlocutors. These two concepts are important for ' mutual respect' and not hurting the feelings of others. According to A.P. Sadokhin, the structure of the Japanese language " causes uncertainty, verbs are placed at the end of a sentence, so what is said can be understood by listening to the end of the sentence" [8, p. 142]. The Japanese can express their opinions for a long time without expressing them clearly.

In Japan, the terms " honne and tatemae" are often used in conversation, and even when translated into Uzbek, they are rarely fully understood due to differences between Japanese and Uzbeks in intercultural communication. They can be described as follows: honne is an expression of true intention; "spiritual thought"; tatemae is an official opinion that needs to be expressed; words are a superficial expression of what society expects of man.

Pauses in the conversation and not finishing the sentence allow the speaker not to offend the other person without losing face. According to B. Rudofsky, " The Japanese think that it is not important that they do not express their opinions. For them, the nuances of etiquette are more important than the subtleties of syntax or grammar. The subtlety of speech is measured by its comprehensibility. And so it is not surprising that silence has become the highest means of communication " [9. B. 154].

Japanese

proverb語るのは金、黙するのは金(kataru no va gin, damasuru no wa kin) "[10, p. 56]. - Proverbs such as "The word is silver, silence is gold" show that the Japanese value silence more than speech. Among the
Japanese proverbs about silence, there are cases when it is better to remain silent and not interfere in what is happening: 沈黙に害なし(timmokunigainashi) - "There is no harm in silence" and二度聞いて、一度もの言え(ni do kiite, ichi do mono ie) »[10, B. 56]. - "Listen twice, say once." In general, in Japan, it is not uncommon to be asked a lot of questions, even if something is misunderstood.

\section{Classification of silences that occur during discourse}

In previous research, it can be seen that the attitude of the interviewees to silence depends on where the silence occurs. Four types of silence: " pause," "emptiness," "interruption," and " conscious / limited silence" were described by Sacs,Schegloff\& Jefferson and Levinson. [11, pp. 696735].

First, a pause is a silence between words of the speaker.

The pause occurs in the middle of the conversation or after a change in the content of a conversation, but during the conversation the pause is repeated along with the changes [11, p.715]. This silence is used when divided into units, such as words, grammar, and phonetics. [12].

This is also seen in encouraging the participants to understand the word. Therefore, the pause can be interpreted as the silent action of the speaker holding the pause. Consider the following discourse on the time required to prepare a report:

$1 \mathrm{~A}:$ でも嫌いな:

2.B:なんだろ

3.レポート

をやるのって凄く時間がかかるじやないですか？

$\rightarrow 3(1.0)$

4. B: あ: そうですね

5.A：あ(.)かかんないですか?

6.そうするとたとえば資料集めもちょっと

7.なんか

8とー—手間取っちやったりとかして ，うまく文章がまとまんなかったりとかして 
CURRENT RESEARCH JOURNAL OF PHILOLOGICAL SCIENCES 2(8): 50-55,

May 2021 DOI: https://doi.org/10.37547/philological-crjps-02-08-12

ISSN 2767-3758

(C)2021 Master Journals

\section{Crossref dol 81 Google}

Accepted26 ${ }^{\text {th }}$ August, 2021 \& Published 31 th August, 2021

There are two interpretations of the onesecond silence seen in the third line.

1) A conscious / limited silence action that indicates an answer

The first interpretation is that $\mathrm{B}$ is a conscious / limited silence that occurs when speech changes from A to B.

In 1-2 speech acts, A tells B that it will take a long time to write a report.

Therefore, in the next 3 speech act, A asks the question and $\mathrm{B}$ is expected to answer the question. However, B did not respond immediately, but after a second of silence (line 3), he responded (speech act 4).

That is, the third-line silence can be thought of as a conscious / limited silence of B, resulting from B' $s$ delay in response.

Note the answer of B in the 4th speech act. The conscious / limited silence seen in this discourse takes place immediately after question $\mathrm{A}$, and a situation occurs that requires $\mathrm{B}$ to answer, so $\mathrm{B}$ interrupts the answer or expresses some disagreement. However, the third line gives the impression that there are a few negative nuances of silence, as B in turn "in the fourth speech act" is that so? he says.

As can be seen from the above, the silence seen in this discourse can be considered a conscious / limited silence by B due to the delay in answering this question. This conscious / limited silence affects expected answers or disagreements due to delays in answering questions.

\section{2) A silent action to express disagreement}

The second interpretation is that this silence is deleted. The words B in speech 4 and A in speech 5 coincide almost simultaneously. Apparently, he was aware of what A and B were saying, and spoke in Act 5 after hearing the content. Perhaps A began to speak in Act 5, focusing on the silence in Act 3. In this way, it can be said that the silence in line 3 perceives $B$ as a silent answer," i.e., A's opinion as silent.

Focusing on the form of the verbs encountered in the questions in the 2 nd and 5 th speech acts, the silence in line 3 can be interpreted and analyzed as follows. The silence between the negative forms of the affirmative form "time is needed" in the second line and the affirmative form "time" in the fifth line plays an important role in making the difference between the two concepts of reporting. In the second line, A: "It takes time, doesn't it?"

Using the other party's consent form, B takes the same amount of time to prepare a report as he does. It reveals the recognition that he is a person. However, since B has turned off his voice in line 3, A uses a negative expression: "Isn't that so?" In line 5 and B's "Doesn't time go by?" requires confirmation in the form of a question. Thus, it can be seen from this speech act that B cannot produce a report in a short time.

Hence, A interprets the silence in this speech act as B not joining the first question.

It can be said that B' s first question is interpreted as an expression of " protest".

In contrast, he realized that his interlocutor would not finish the report in a short time. So in the next question, he probably asked the question using a negative form, reflecting this idea. In the above discourse, the deletion of the word in line 3 can be interpreted by $\mathrm{B}$ as a negative opinion or a disagreement for $\mathrm{A}$.

\section{Conclusion}

Thus, in Japanese discourse, communication is determined not only by words, but also by gestures. 
CURRENT RESEARCH JOURNAL OF PHILOLOGICAL SCIENCES 2(8): 50-55,

May 2021 DOI: https://doi.org/10.37547/philological-crjps-02-08-12

ISSN 2767-3758

(C)2021 Master Journals

Crossref do: 81 Google

Accepted26 ${ }^{\text {th }}$ August, 2021 \& Published 31 ${ }^{\text {th }}$ August, 2021

Communication is often associated with the meanings of certain cues of communicators gestures, nods, smiles, lip movements, eyebrows and other facial expressions, as well as reactions to silence. In Japanese, the saying "I understand ten times more than I hear" is reflected in the fact that in a series of discourses there is often no need for words at all. It became clear that the Japanese understood each other very well in conversation without words, and that words lost many nuances.

Thus, by defining silence in terms of dynamic and spiritual interactions, it was found that the interpretation of silence can be understood in several layers, taking into account the speaker and the silence interactions. That is, even if the silence is the same, it can have multiple interpretations from different perspectives. Silence can be classified as an action that allows for multi-layered interpretation.

\section{REFERENCES}

1. Davies R. J., Ikeno O. The Japanese mind. Understanding contemporary Japanese culture. Tokyo: Tuttle Publishing, 2002. 270 p.

2. Халмурзаева, Н. Т. (2016). Имплицитная форма вежливости в Японской лингвокультуре: способы выражения. European Journal of Humanities and Social Sciences, (4), 19-22.

3. Nasirova, S. A., Hashimova, S. A., \& Rikhsieva, G. S. (2021). THE INFLUENCE OF THE POLITICAL SYSTEM OF CHINA ON THE FORMATION OF SOCIAL AND POLITICAL TERMINOLOGY. Journal of Central Asian Social Studies, 2(04), 10-17.

4. Mirzakhmedova, K. V. (2021). Comparative Analysis of General Words-Terms In Persian and Uzbek Languages. Psychology and Education Journal, 58(1), 1050-1056.

5. Ashiralievich, VA va \& Vasilovna, MK (2020). Sharq tillarini o'rganishning interaktiv vositasi. Osiyo ko'p o'lchovli tadqiqot jurnali (AJMR) , 9 (3), 78-86.

6. Hashimova, S. A., \& Nasirova, S. A. (2021). FEATURES OF FORMING OF ANIMATED NOUNS WITH THE AFFIXES IN MODERN CHINESE LANGUAGE. Journal of Central Asian Social Studies, 2(04), 1-10.

7. Халмурзаева, Н. Т. (2020). ТИПология ЯПОНСКОГО КОММУНИКАТИВНОДЕЛОВОГО ЭТИКЕТА.Вестник науки $и$ образования, (14-2 (92)).

8. Рихсиева, Г. Ш. (2014). ОЛИЙ ТАЪЛИМ МУАССАСАЛАРИ РЕЙТИНГИ-СИФАТ ВА ТАРАҚҚИЁТ ОМИЛИ. Oliy ta'lim taraqqiyoti istiqbollari $=$ Perspectives of higher education development $=$ Перспективы развития высшего образования: To 'plam № 2/ma'sul muharrir MA Rahmatullayev.-Издательство: Vita Color T.: 2014.-161 b., 29.

9. Omonov, Q. S. (2019). THE WAYS OF OFFICIALISATION OF THE DOCUMENTS AND THE PROBLEM OF LEGITIMIZATION OF THE TEXT. Научные вести, (7), 43-51.

10. AMANOV, K. (2015). THE MATTER OF DIVIDING AGES IN HISTORY OF TURKIC OFFICIAL METHOD. Turkish Studies (Elektronik), 10(12), 57-68.

11. Mirzaxmedova, H. (2020). TERMS MADE FROM THE ORIGINAL IRANIAN VOCABULARY IN PERSIAN. Philology Matters, 2020(1), 137-145.

12. Омонов, К. Ш. (2015). Типы деловых документов в истории старотюркского 
CURRENT RESEARCH JOURNAL OF PHILOLOGICAL SCIENCES 2(8): 50-55,

May 2021 DOI: https://doi.org/10.37547/philological-crjps-02-08-12

ISSN 2767-3758

(C)2021 Master Journals

Crossref dol 81 Google

Accepted26 $6^{\text {th }}$ August, 2021 \& Published 31 ${ }^{\text {th }}$ August, 2021

литературного языка. Paradigmata poznani,

(3), 71-74.

13. Khalmurzaeva, N. T. (2019). СПОСОБЫ КЛАССИФИКАЦИИ ВЕРБАЛЬНЫХ ФОРМ КАТЕГОРИИ ВЕЖЛИВОСТИ В ЯПОНСКОМ яЗЫКЕ. Theoretical \& Applied Science, (12), 27-33.

14. Mirzakhmedova, H. V., Omonov, K. S., \& Khalmurzaeva, N. T. (2021). METHODS OF IMPROVING LANGUAGE SKILLS USING MEDIA SOFTWARE. Journal of Central Asian Social Studies, 2(03), 47-55.

15. Khalmurzaeva, N. T. (2020). Peculiarities of intercultural understanding in Uzbek and japanese verbal communication. ACADEMICIA: $\quad A n$ International Multidisciplinary Research Journal, 10(11), 1473-1481. 